\title{
Migration and Religious Freedom: the Legislative and Judicial Framework at International and European Level
}

\author{
Andrea Santini and Monica Spatti
}

\section{Introduction}

Despite being a fundamental human right, freedom of religion is still violated in many parts of the world today.* The violation of this right can take on different forms. Sometimes, it simply consists of preventing people from choosing their own religion. More frequently, there are abuses. In some countries people belonging to religious minorities are discriminated and are prohibited to exercise some basic rights such as participating in public elections, applying for jobs or freely circulating in the country. Sometimes religious minorities are subject to detention, torture or other cruel treatments.

These persecutions, which can be of different kind, represent, as described in Chapters 5 and 10, a driving factor of emigration. Indeed, oppressed people try to migrate to a place where they hope to live in peace. Once they left their country of origin, they try to apply to some form of protection from the State they emigrated to. The purpose of this contribution is to verify the conditions under which legal protection can be granted to those individuals who have left their country of origin due to religious persecutions. The research will focus on both international and European law, as well as the relevant case law on the matter. Accordingly, it will be necessary to understand first what freedom of religion is from the point of view of international and European law. Secondly, it will be analyzed what kind of protection can be granted to those people who are leaving their country due to a violation of their freedom of religion.

Freedom of religion or belief is a fundamental right recognized in several sources of international law. It was first proclaimed in art. 18 of the Universal

\footnotetext{
* Although this chapter is the result of common reflections and work, paragraphs 1, 2 and 3 have been drafted by Monica Spatti and paragraphs 4 and 5 by Andrea Santini.

(C) ANDREA SANTINI AND MONICA SPATTI, 2020 | DOI:10.1163/9789004429604_005
}

This is an open access chapter distributed under the terms of the CC BY-NC-ND 4.0 license. Spatti - 9789004429604 
Declaration of Human Rights and then enshrined in several legal acts both binding and not binding, regional ${ }^{1}$ and universal. ${ }^{2}$ It is worth to recall, in particular, art. 18 of the International Covenant on Civil and Political Rights (ICCPR), ${ }^{3}$ and art. 9 of the European Convention on Human Rights (ECHR). ${ }^{4}$

Commonly known as "freedom of religion or belief", the full definition of this human right is "freedom of thought, conscience, religion or belief". Accordingly, it recognizes not only the right to have any religion or belief, but also the right not to profess anyone. ${ }^{5}$ The inclusion of freedom of thought and conscience in the definition has the purpose to cover also atheism and not only strictly religious convictions (Evans, 2001: 40). The formula adopted in many legal acts is so wide to include also the right not to reveal religious convictions or beliefs to anyone. ${ }^{6}$

International law does not define what "religion" is. Normally international courts and other bodies in charge of the protection of human rights interpret it in a broad sense. More precisely, the concept of religion cannot be limited to established confessions or those "with institutional characteristics or practices analogous to those of traditional religions".7 For this reason, international

1 Among the human rights regional treaties recognising the right to freedom of religion or belief see: American Convention on Human Rights, San José, 22 November 1969, art. 12; African Charter on Human and People Rights, Nairobi, 27 June 1981, art. 8.

2 Among the universal binding acts see, for example: Convention relating to the Status of Refugees, Geneva, 28 July 1951, art. 4; Convention on the Rights of the Child, New York, 20 November 1989, art. 14; International Convention on the Protection of the Rights of All Migrant Workers and Members of Their Families, New York, 18 December 1990, art. 12. Among the other international acts see, inter alia: the Declaration on the Elimination of All Forms of Intolerance and of Discrimination based on Religion of Belief, proclaimed by General Assembly resolution No. $36 / 55$ of 25 November 1981; the Declaration on the Rights of Persons Belonging to National or Ethnic, Religious and Linguistic Minorities, adopted by General Assembly resolution No. 47/135 of 18 December 1992.

3 New York, 16 December 1966.

4 Rome, 4 November $195^{\circ}$.

5 See General Comment No. 22, adopted by the Human Rights Committee on 30 July 1993, para 5. See the following judgements of the European Court of Human Rights: Kokkinakis v. Greece, 25 May 1993, par. 31; Buscarini and others v. San Marino (GC), 18 February 1999, par. 34; Alexandridis v. Greece, 21 February 2008, par. 32.

6 General Comment No. 22, cit., par. 3. See also the European Court of Human Rights' judgements Sinan Isik v. Turkey, 2 February 2010, par. 49-52, and Dimitras and others v. Greece, 3 June 2013, par. 35 .

7 General Comment No. 22, cit., par. 2. The European Court of Human Rights has recognized the guarantees coming from art. 9 ECHR to traditional religions as Alevism (judgement Izzettin Doğan and others v. Turkey (GC), 26 April 2016, par. 114), Buddhism (judgement Jakóbski v. Poland, 7 December 2010), Hinduism (judgement Kovalkovs v. Latvia, 31 January 2012), Islam (judgement Hassan et Tchaouch v. Bulgaria (GC), 26 October 200o), Taoism (decision X. v. United Kingdom, 18 May 1976), Sikhism (decision Jasvir Singh v. France, 30 June 2009), but also 
human rights bodies do not distinguish between "religion" and "sect". The European Court of Human Rights has applied art. 9 ECHR regardless any qualification coming from national authorities. ${ }^{8}$ The term "belief" has also been interpreted in a wide sense in order to include convictions of non-religious nature, such as pacifism, ${ }^{9}$ anti-abortion convictions ${ }^{10}$ and vegetarianism. ${ }^{11}$ At the same time, the concept of belief is not so broad to include any personal preference. According to the European Court of Human Rights, in order to be protected by the Convention, the personal conviction must have "a certain level of cogency, seriousness, cohesion and importance"12 (Bielefeldt, 2015: 16-17).

Once defined what freedom of religion or belief is, it is possible to identify two dimensions where it applies: the forum internum and the forum externum. The forum internum regards the internal sphere of the individual and consists of the right to have a freely chosen religion or belief. Accordingly, it cannot be subject to any coercion. The forum externum instead consists of the freedom to profess a certain religion or belief. As it may have consequences on the others, it can be subject to limitations. Therefore, freedom of religion is not an unconditional and absolute principle, such as the prohibition of torture and slavery or freedom of opinion. Freedom of religion or belief as prescribed by international law simply implies the prohibition of coercion: no one can be forced to have or adopt a religion against their will. ${ }^{13}$

The right to change religion is the most controversial component of freedom of religion or belief. The travaux préparatoires of several treaties reveal that State representatives had passionate debates on the opportunity to recognize the right to change religion. Some countries were openly against it by arguing that it may encourage unwelcome proselytism and undermine national

to more recent religions as Aumism of Mandaron (judgement Association de Chevaliers du Lotus d'Or v. France, 31 January 2013), Osho (judgement Mockuté v. Lithuania, 27 February 2018, par. 121), Mormonisme (judgement The Church of Jesus Christ of LatterDay Saints v. United Kingdom, 4 March 2014), the Raelian movement (decision F.L. v. France, 3 November 2005), Jehovah's Witnesses (judgement Jehovah's Witnesses of Moscow and others $v$. Russia, 10 June 2010).

8 The European Court of Human Rights has not excluded from the guarantees coming from art. 9 groups as Scientology (decision X. and Church of Scientology v. Sweden, 5 May 1979), druidism (decision Chappell v. United Kingdom, 14 July 1987), the "Divine Light Zentrum" (decision Omkarananda and Divine Light Zentrum v. Switzerland, 19 March 1981), without investigating their qualifications.

$9 \quad$ European Court decision Arrowsmith v. United Kingdom, 16 May 1977.

10 European Court decision Knudesn v. Norway, 3 March 1985.

11 European Court decision w.c. v. United Kingdom, 1o February 1993.

12 European Court judgement Campbell and Cosans v. United Kingdom, 22 March 1983, par. 293 .

13 General Comment No. 22, cit., par. 5 . 
cohesion $^{14}$ (Bielefeldt et al, 2016: 57-58). For this reason, while the right to change religion was expressly mentioned in the Universal Declaration on $\mathrm{Hu}-$ man Rights and in the ECHR, the ICCPR adopted the more nuanced formula of "religion or belief of one's choice". Despite this reticence, the right to change religion constitutes a necessary component of freedom of religion as underlined by the Human Rights Committee in the General Comment No. 22.

The right to change or abandon a religion is not granted in every country yet. While few governments punish this behavior through criminal sanctions, other countries foresee some other consequences, such as limiting access to education, employment, as well as the right to travel and vote (Bielefeldt et al., 2016). This happens in particular in those States that have an official religion (Bielefeldt et al., 2016). Quite interestingly, international law does not prohibit States to choose an official religion, even if this choice may increase the risk of discriminations and persecutions against minorities. ${ }^{15}$ As pointed out by the Human Rights Committee "the fact that a religion is recognized as a State religion (...) or that its followers comprise the majority of the population, shall not result in any impairment of the enjoyment of any of the rights under the Covenant". 16

The forum externum of freedom of religion or belief consists of the right to manifest any religion or belief. This freedom has a private as well as a community dimension, as it protects the manifestation of belief "in worship, observance, practice and teaching" both in public and in private (Clark, Durham, 2015). The collective aspect of freedom of religion or belief gives communities the right to perform "acts integral to the conduct by religious groups of their basic affairs", ${ }^{17}$ this including the right to establish places for worship, ${ }^{18}$ select and train leaders, ${ }^{19}$ establish religious schools, etc. More generally, the right to profess a religion or belief does potentially include a broad range of acts, such as the use of ritual formulas, observance of holidays and of dietary regulations, as well as wearing distinctive clothing. ${ }^{20}$

14 The recognition of the right to change religion in art. 18 of the Universal Declaration on Human Rights is the main reason for the abstention of Saudi Arabia at the vote. See A/C.3/SR.289, par. 40-47.

15 According to H. Bielefeldt, 2015: 20 "Freedom of religion or belief, understood as a human right for all without discrimination, can thus become a powerful argument for establishing secular constitutions and secular legal orders".

16 General Comment No. 22, cit., par. 9.

17 Ivi, par. 4.

18 See the judgement of the European Court of Human Rights Association for Solidarity with Jehovah Witnesses and others v. Turkey, 24 May 2016, par. 104-108.

19 European Court of Human Rights judgement Hasan and Chaush v. Bulgaria (GC), 26 October 2000, par. 85-89.

20 General Comment No. 22, cit., par. 4. 
As it has already been said, the right to manifest a religion or belief can be subject to limitations. According to art. 18 (3) ICCPR and art. 9 (2) ECHR, legitimate restrictions must be prescribed by the law and pursue a legitimate aim, such as public safety, public order, health, moral or the protection of rights and freedom of others. Moreover, the restriction is legitimate as long as it is necessary to achieve the defined aim, thus requesting an evaluation of the proportionality of the measure.

Freedom of religion or belief is also recognized within the European Union legal system. From a EU law perspective, this right is directly connected to the values on which the Union is based -such as democracy, the rule of law and respect of human rights- as it contributes to their achievement. ${ }^{21}$ In particular, art. 10 of the Charter of Fundamental Rights (CFR) of the European Union presents the same formulation of freedom of religion outlined in art. 9 ECHR. ${ }^{22}$ However, art. 10 of the Charter does not provide a specific discipline on the possible limitations of freedom of religion. This depends on the decision of the drafters to introduce a general provision in art. $52 \mathrm{CFR}$ allowing limitations to all rights and freedoms provided by the Charter. According to par. 3 of this provision, in particular, when the Charter contains rights which correspond to the rights guaranteed by the ECHR, "the meaning and scope of those rights shall be the same as those laid down" by the ECHR. As clarified in the explanations relating to the EU Charter of Fundamental Rights, as the right guaranteed in art. 10 (1) CFR corresponds to the right guaranteed in art. 9 of the ECHR, limitations should also comply with the discipline that the latter provision provides on the matter in par. 2.

\section{$3 \quad$ Refugees and the Principle of Non-refoulement}

Another important treaty for the protection of freedom of religion or belief is the Geneva Convention on the status of refugees adopted in 1951 (hereinafter: Geneva Convention). ${ }^{23}$ It represents the only global treaty protecting people who are escaping from their country of origin due to the risk of serious

21 See the EU Guidelines on the promotion and protection of freedom of religion or belief, adopted by the Council of the European Union, 24 June 2013, par. 1.

22 Charter of Fundamental Rights of the European Union, Strasbourg, 12 December 2007.

23 The Geneva Convention is integrated by the Protocol of New York, adopted the 31 January 1967 , that removed, for those States that have ratified it, the geographical and temporal restrictions established in the Convention according to which the Geneva Convention applied only to persons who became refugees as a result of events occurring before 1 January 1951 in Europe. 
violations of their fundamental rights, including freedom of religion or belief. According to art. 1 (A) (2) of the Geneva Convention, a refugee is someone who

owing to well-founded fear of being persecuted for reasons of race, religion, nationality, membership of a particular social group or political opinion, is outside the country of his nationality and is unable or, owing to such fear, is unwilling to avail himself of the protection of that country.

The people falling under this definition may obtain the status of refugee if the country where they ask protection has ratified this Convention. ${ }^{24}$

Also the European Union takes care of people obliged to escape from their country of origin. More precisely, Directive 2011/95/EU recognizes two kinds of protection: the "refugee status" and the "subsidiary protection". ${ }^{25}$ The definition of refugee outlined in art. $2(d)$ of the Directive recalls the same formulation adopted by the Geneva Convention, which focuses on the risk of persecution. At the same time, the Directive is more precise as it specifies in details the requirements to be considered a refugee. For example, aside from defining explicitly what acts can be qualified as "persecution" (see infra par. 4), art. 10 also explains the possible reasons behind such behavior. Furthermore, it is also interesting for the purpose of this research the fact that art. $10(1)(b)$ provides a definition of religion: this consisting of "the holding of theistic, nontheistic and atheistic beliefs, the participation in, or abstention from, formal worship in private or in public, either alone or in community with others, other religious acts or expressions of view, or forms of personal or communal conduct based on or mandated by any religious belief". The definition is clearly very wide in accordance with the approach adopted by the treaties on the protection of human rights mentioned above.

Quite interestingly, EU law also clarifies who the actors of the persecution may be. This is something the Geneva Convention has left rather nuanced, by simply stating that the refugee "is unable (...) or unwilling, to avail himself of the protection" of his country of origin. From this formulation, it has been possible to deduce that refugees are "unwilling" when the persecution comes

24145 States have ratified the Convention. See https://www.unhcr.org/protect/PROTEC TION/3b73bod63.pdf.

25 Directive 2011/95/EU of the European Parliament and of the Council of 13 December 2011 on standards for the qualification of third-country nationals or stateless persons as beneficiaries of international protection, for a uniform status for refugees or for persons eligible for subsidiary protection, and for the content of the protection granted, in of $\mathrm{L} 337$, 20 December 2011, pp. 9-26. 
directly from the State, and "unable" when the country of origin is not able not protect them from persecution coming from others. Art. 6 of Directive 2011/95/EU supports this interpretation, as it explains that the actors of persecution include not only States but also parties or organizations that control the territory of the State, totally or for a substantial part, and non-state actors when the authorities don't want, or are unable to, provide protection. ${ }^{26}$

Directive 2011/95/EU regulates also another situation, which has been ignored in the Geneva Convention: the possibility to become refugees after having left the country of origin. Better known as refugees "sur place", this phenomenon is particularly important for the purpose of this research because it covers the issue of those who change their religion after having left their country. Accordingly, art. 5 of the Directive clearly states that the fear of being persecuted may be also based "on events which have taken place since the applicant left the country of origin". ${ }^{27}$

Subsidiary protection takes care of those who are escaping from their country not due to the risk of persecution but for other reasons. According to art. 2 (f) of Directive 2011/95/EU, a person is eligible for subsidiary protection when he or she "does not qualify as refugee but in respect of whom substantial grounds have been shown for believing that the person concerned, if returned to his or her country of origin, or in the case of a stateless person, to his or her country of former habitual residence, would face a real risk of suffering serious harm (...) and is unable, or, owing to such risk, unwilling to avail himself or herself of the protection of that country". This kind of protection focuses on the risk of suffering serious harm in the country of origin. As clarified in art. 15 of the Directive, serious harm may consist of death penalty, torture, inhuman or degrading treatments, and punishments in the country of origin or, again, "serious and individual threat to a civilian's life or person by reason of indiscriminate violence in situations of international or internal armed conflict". The subsidiary protection can therefore have a very wide application.

The recognition of the status of refugee implies a series of guarantees expressly established in the Geneva Convention, including the right to access housing, labor market, freedom of movement within the territory of the State, right to obtain travel documents, etc. The same guarantees are also provided by Directive 2011/95/EU in favor of those who have obtained either the status of refugees or the subsidiary protection.

26 Art. 6 also applies in relation to the subsidiary protection. Between the European Court of Human Rights judgements see H.L.R. v. France, 29 April 1997, par. 32, and Ahmed v. Austria, 17 December 1997, par. 44.

27 Art. 5 also applies in relation to the subsidiary protection. 
The most important form of protection for refugees is provided by the principle of non-refoulement outlined in art. 33 of the Geneva Convention and extended by EU law also to the beneficiaries of subsidiary protection. According to art. 33 (1) "No Contracting State shall expel or return ('refouler') a refugee in any manner whatsoever to the frontiers of territories where his life or freedom would be threatened on account of his race, religion, nationality, membership of a particular social group or political opinion". Therefore, those who have obtained the status of refugee cannot be expelled or returned to a country where there is a risk of persecution. Within the Geneva Convention the principle of non-refoulement is not absolute, as art. 33 (2) establishes that " $(\mathrm{t}) \mathrm{he}$ benefit of the present provision may not, however, be claimed by a refugee whom there are reasonable grounds for regarding as a danger to the security of the country in which he is, or who, having been convicted by a final judgment of a particularly serious crime, constitutes a danger to the community of that country". Similar provisions are provided in art. 21 of Directive 2011/95/EU.

The principle of non-refoulement has been recognized in many international and regional treaties ${ }^{28}$ and its content has developed in accordance with the evolution of international law on human rights. An important contribution in this regard was given by the case law of the European Court of Human Rights. In the well-known case Soering v. United Kingdom of $1989,{ }^{29}$ the European Court claimed that States parties cannot expel, return, extradite or reject any person towards countries where they risk being subject to torture and degrading or inhuman treatments and punishment (all these behaviors being illegal in accordance with art. 3 of the Convention). It should be noticed that the ECHR does prevent States from expelling or rejecting people towards countries where there is a well-founded risk that the individual may be subject to a punishment or inhuman treatment. ${ }^{30}$ The risk must be real and regard specifically the person subject to expulsion, thus excluding a situation of general risk concerning either an entire community or other people presenting a similar

28 AU Convention Governing the Specific Aspects of Refugee Problems in Africa, Addis Abeba, 10 September 1969, art. 2 (3); American Convention on Human Rights, cit., art. 22 (8); Convention against Torture and Other Cruel, Inhuman or Degrading Treatment or Punishment, New York, 10 December 1984, art. 3; Charter of Fundamental Rights of the European Union, art. 19 (2).

29 Judgement of 7 July 1989.

30 See, inter alia, the European Court judgements Cruz Varas and others v. Sweden, 20 March 1991, par. 75, Chahal v. United Kingdom, 15 November 1996, par. 74, and H.L.R. v. France, cit., par. $33-34$. 
status or background. ${ }^{31}$ However, in cases of extreme violence, it is not necessary to demand specific evidence of an individual risk, as the latter is implied in the general context. ${ }^{32}$

Similarly, art. 2 ECHR, on the right to life, has been applied in a way to prevent States from expelling, returning, extraditing or rejecting anyone towards a country where there are substantial grounds to believe that their life is at risk. ${ }^{33}$

Clearly, the case law of the European Court does not focus specifically on refugees. The ECHR protects all human beings, regardless the personal status of the beneficiaries. It is remarkable that the European Court granted protection regardless any consideration on the danger the right-holders may represent for the country or the community where they live. ${ }^{34}$ Indeed, the prohibition of torture and inhuman treatments, as well as the right to life cannot be balanced with other interests or rights. ${ }^{35}$ According to the Court, governments have sufficient instruments to limit dangers for the security of the community, i.e. applying imprisonment after a due trial.

In addition to the evolution "rationae personae", the principle of non-refoulement has also evolved "rationae materiae". While art. 33 of the Geneva Convention prohibits expulsion and return, the rejection at the frontier is not expressly contemplated. Looking at the preparatory works of the Convention, it is quite clear that the contracting States did not want to regulate this situation (Aga Khan, 1976; Goodwin-Gill, 1996). Nowadays, however, the gap has been filled: it is generally acknowledged that the principle of non-refoulement does prevent rejection at the frontier (Coleman, 2003; Stenberg, 1989). ${ }^{36}$

31 European Court judgements Vilvarajah and others v. United Kingdom, 30 October 1991, par. 111, and H.L.R. v. France, cit., par. 41.

32 European Court judgements Salah Sheekhv. The Netherlands, 11 January 2007, par. 148, and NA. v. United Kingdom, 17 July 2008, par. 115-117.

33 European Court decisions A.A. v. Norway, 21 October 1993, Sinnarajah v. Switzerland, 11 May 1999, and judgements Bahaddar v. the Netherlands, 19 February 1998, par. 75-78, and Kaboulov v. Ukraine, 19 November 2009, par. 99.

34 In the judgement Chahalv. United Kingdom, cit., par. 80, the European Court has affirmed that "the activities of the individual in question, however undesirable or dangerous, cannot be a material consideration. The protection afforded by Article 3 is thus wider than that provided by Articles 32 and 33 of the United Nations 1951 Convention on the Status of refugees". See also judgements Ahmed v. Austria, cit., par. 41 and Saadiv. Italy, 28 February 2008, par. 127.

35 Saadiv. Italy, cit., par. 140.

36 See: Declaration on Territorial asylum, adopted by General Assembly resolution No. 2312(XXII), 14 December 1967, art. 3 (1); Committee of Ministers of the Council of Europe, resolution No. (67) 14 on Asylum to persons in danger of persecution, 29 June 1967, par. 2; Directive 2013/33/EU of the European Parliament and of the Council of 26 June 2013 
The evolution of the principle of non-refoulement triggered by the case law of the European Court has influenced international law as a whole. The Human Rights Committee for example, as well as the Committee against Torture, have repeatedly recognized that "the principle of 'non-refoulement' of persons to another State where there are substantial grounds for believing that they would be in danger of being subjected to torture" or inhuman or degrading punishment or treatment, or would be in a danger for their life, is absolute (Bouziri, 2003; Phuong, 2007; Weissbrodt, Hörtreiter, 1999). ${ }^{37}$

\section{4}

\section{Religious Persecutions}

As seen above, the notion of refugee can be deduced from the one of persecution. This is indeed the situation which allows to access the status of refugee. While the Geneva Convention does not provide any definition of persecution, EU law is more precise. Art. 9 (1) of Directive 2011/95/EU states that an act of persecution must: ( $a$ ) be sufficiently serious by its nature, or because it is repeated, "as to constitute a severe violation of basic human rights"; $(b)$ or "be an accumulation of various measures, including violations of human rights which is sufficiently severe as to affect an individual in a similar manner as mentioned in point (a)". The notion of persecution is therefore defined by an objective criterion, meaning "the nature and intrinsic severity of the act or the situation experienced as well as the consequences suffered by the person concerned in his country of origin".38

Art. 9 (1) specifies that the most relevant affected human rights are those which cannot be derogated according to art. 15 (2) ECHR, and therefore are considered absolute. These are: right to life (art. 2); prohibition of torture and degrading or inhuman treatments and punishments (art. 3); prohibition of slavery (art. 4 (1)); nulla poena sine lege (art. 7). The concept of persecution as established in the Directive is consistent with the case law of both the European Court of Human Rights and the Human Rights Committee: as it was already explained, these authorities have already clarified that States cannot

laying down standards for the reception of applicants for international protection, in of $\mathrm{L}$ 180, 29 June 2013, pp. 96-116, art. 3.

37 See Human Rights Committee, General Comment No. 20, par. 9 and 12, and Committee against Torture, General Comment No. 4 (2017), par. 9-11.

38 Opinion of Advocate General Bot, 19 April 2012, joined cases C-71/11 and C-99/11, Bundesrepublik Deutschland v. Y and Z, par. 53 . 
expel, return, extradite or reject people towards countries where they risk being subject to torture and degrading or inhuman treatments and punishment or to be deprived of their life.

Art. 9 (2) of Directive 2011/95/EU gives some examples of acts of persecution. These are, first of all, "acts of physical or mental violence", thus including torture, inhuman and degrading treatment and punishment. ${ }^{39}$ Other examples recalled in art. 9 (2) are: "legal, administrative, police, and/or judicial measures which are in themselves discriminatory or which are implemented in a discriminatory manner", "prosecution or punishment which is disproportionate or discriminatory", and, again, "denial of judicial redress resulting in a disproportionate or discriminatory punishment". These examples focus on the concept of discrimination and disproportion. At the same time, a mere discrimination does not lead to a persecution. Par. 2 must be read in conjunction with par. 1: a discrimination does not necessarily lead to a persecution, especially if it doesn't also cause some serious violation of human rights.

When focusing on freedom of religion, it is necessary to verify what behaviors may be qualified as a religious persecution. As seen above, persecution is a personal attack, which may undermine the most essential rights. Accordingly, only serious violations of the right to freedom of religion or belief could be considered as a form of persecution. This has been already clarified by the European Court of Human Rights and the Court of Justice of the European Union in two important cases regarding the expulsion of asylum seekers towards countries where they may have been persecuted because of their religious affiliation. The European Court of Human Rights in the case Z. and T. $v$. United Kingdom, ${ }^{40}$ and the Court of Justice of the European Union in the case Bundesrepublik Deutschland $v$. $Y$ and $Z,{ }^{41}$ stated that the mere violation of freedom of religion or belief does not constitute a persecution, even if there is a radical ban to practice the religion of own choice. A violation of the right to freedom of religion or belief may represent a persecution (thus allowing the

39 About the distinction between "inhuman" and "degrading", the European Court has stated that "inhuman" is a premeditated treatment, which "was applied for hours at a stretch and caused either actual bodily injury or intense physical and mental suffering", while a treatment can be considered "degrading" when it is "such as to arouse in its victims feelings of fear, anguish and inferiority capable of humiliating and debasing them and possibly breaking their physical or moral resistance" (see judgement Jalloh v. Germany, 11 July 2006, par. 68). Torture, instead, is an aggravated form of inhuman or degrading treatment.

40 Decision of 28 February 2006.

41 Judgement of 5 September 2012, joined cases C-71/11 and C-99/11. 
possibility to obtain the status of refugee) only when the person, "as a result of exercising that freedom in his country of origin, runs a genuine risk of, inter alia, being prosecuted or subject to inhuman or degrading treatment or punishment" or being tortured or killed. ${ }^{42}$ Therefore, the violation of freedom of religion or belief does not automatically allow the possibility to obtain protection (Labayle, 2012). It is instead necessary to look at the consequences coming from that violation. Only if the violation consists of acts of torture or degrading and inhuman treatments, or a threat to life or, again, a risk of being prosecuted for religious affiliation, the claimant can obtain protection. The Human Rights Committee adopted the same view. The case X. c. Denmark concerned an asylum seeker who refused returning to his country of origin where he risked incarceration without trial and torture in detention due also to his refusal to undertake military service on the basis of conscience. ${ }^{43}$ The Committee declared that the allegations were founded and stated that the deportation would constitute a violation of art. 7 of the ICCPR, which is the norm recognizing the prohibition of torture and degrading and inhuman treatments and punishments (Bielefeldt et al., 2016: 411-413). ${ }^{44}$

The judgement Bundesrepublik Deutschland $v$. Y and $Z$ of the Court of Justice of the European Union is interesting under another point of view. The national judge asked the Court to consider whether the fear of persecution -which prevents expulsion only if it is supported by evidence- exists even if the person could prevent the persecution "by abstaining from certain religious practice" in the country of origin. ${ }^{45}$ The Court answered that none of the rules of the Directive states that "it is necessary to take account of the possibility open to the applicant of avoiding the risk of persecution by abstaining from the religious practice". ${ }^{46}$ Accordingly, a State cannot allow an expulsion when the person concerned may be safe simply by abstaining from a religious practice or hiding an affiliation. According to the Court of Justice, "where it is established that, upon his return to his country of origin, the person concerned will follow a religious practice which will expose him to a real risk of persecution, he should be granted refugee status". ${ }^{4}$

42 See: decision of the European Court of Human Rights Z. and T.v. United Kingdom, cit., and judgement of the Court of Justice of the European Union, Bundesrepublik Deutschland $v$. $Y$ and $Z$, cit., par. 66-67.

43 Decision of 26 March 2014.

44 Ivi, par. 8.4 and 9.3.

45 Par. 73.

$46 \quad$ Par. 78.

47 Par. 79 . 


\section{$5 \quad$ Concluding Observations}

Everyone in the world must be able to benefit from a series of fundamental rights, which are inherent in the essence of human being. Freedom of religion or belief is certainly one of them. As established in international and European law, and better clarified by international courts and treaty bodies, this right covers a very wide number of situations and can be limited only in few cases. Unfortunately, many countries do not respect freedom of religion, this having a negative impact on the conferral of other fundamental rights. It is therefore understandable that people oppressed for their religion decide to move to another country in order to find a place where they can freely express themselves. In the host State, they ask, first, the right to practice their religion or belief and, second, the right not to be sent back to the country of origin. At the same time, international and European laws on immigration do not automatically protect everybody who cannot effectively exercise their rights in their country of origin. As clearly explained by the European Court of Human Rights and the Court of Justice of the European Union, protection must be reserved to those individuals who are exposed to serious breaches of their fundamental rights. Therefore, a violation of freedom of religion or belief does not automatically grant the right to receive protection. 